\title{
Antimicrobial resistance genes and bacterial diversity in sediments of Guandu River, Brazil
}

Rivers provide essential water resources for humans. However, appear to be reservoirs of antimicrobial-resistant genes and dispersal routes of resistant pathogen because human activities promptly influence them. Sediments are the most propitious substrates for bacteria survival and can act as an antimicrobial reservoir. Three sediment samples were collected upstream of the water catchment point of the Guandu Water Treatment Plant (ETA Guandu) to evaluate microbial diversity and antimicrobial resistance genes to sulfonamide (sul1, sul2), tetracycline (tetA, tetB) and beta-lactam (blaCTX-M, blaoxa24 and blaoxa58) by PCR. The most abundant phylum in all samples was Proteobacteria, which was also the most dominant in sediments presenting a pattern already reported in the literature for diversity in tropical and temperate climate rivers. Sulfonamide resistance genes were detected in all samples. The blaCTX-M gene was detected only in one sample, and tetA, tetB, blaoxa24 and blaoxa58 genes were not found in any sample. The presence of antimicrobial resistance genes sul1, sul2, and blaCTX-M indicate that sediments can act as a reservoir of resistance. These findings will provide new data about the bacterial community and antimicrobial resistance genes in Brazilians river sediments.

\section{Genes de resistência a antimicrobianos e diversidade bacteriana em sedimentos do Rio Guandu, Brasil}

\begin{abstract}
Os rios fornecem recursos hídricos essenciais para os seres humanos. No entanto, eles podem ser reservatórios de genes de resistentes a antimicrobianos e rotas de dispersão de patógenos resistentes, uma vez que as atividades humanas os influenciam prontamente. Os sedimentos são os substratos mais propícios para a sobrevivência das bactérias e podem atuar como reservatórios de antimicrobianos. Três amostras de sedimentos foram coletadas a montante da captação de água da Estação de Tratamento de Água do Guandu (ETA Guandu) para avaliar a diversidade microbiana e a presença de genes de resistência à sulfonamida (sul1 e sul2), tetraciclina (tetA e tetB) e beta-lactâmicos (blaCTX-M, blaoxa24 e blaoxa58) por meio de PCR. O filo mais abundante em todas as amostras foram Proteobacteria, que também foi o mais dominante em sedimentos apresentando um padrão já relatado na literatura para diversidade em rios de clima tropical e temperado. Genes de resistência às sulfonamidas foram detectados em todas as amostras. O gene blaCTX-M foi detectado apenas em uma amostra, e os genes tetA, tetB, blaoxa24 e blaoxa58 não foram encontrados em nenhuma amostra. A presença dos genes sul1, sul2 e blaCTX-M indicam que os sedimentos podem atuar como reservatórios de resistência. Essas descobertas fornecerão novos dados sobre a comunidade bacteriana e genes de resistência a antimicrobianos presentes nos sedimentos fluviais brasileiros.
\end{abstract}

Palavras-chave: Beta-lactâmicos; Diversidade microbiana; Sequenciamento de nova geração; Sulfonamida; Tetraciclina.

Topic: Microbiologia Agrícola e Ambiental

Reviewed anonymously in the process of blind peer
Received: 03/04/2021

Approved: 28/04/2021
Gustavo Souza Lima Sant'Anna (id)

Universidade Federal Rural do Rio de Janeiro, Brasil http://lattes.cnpq.br/2232142901960029

http://orcid.org/0000-0003-4688-0472

gsouzalimas@gmail.com

José Maurício Fajardo da Cunha (iD)

Universidade Federal Rural do Rio de Janeiro, Brasil

http://lattes.cnpq.br/2900048194731107

http://orcid.org/0000-0001-9071-4063

fajardomauriciu@yahoo.com.br

Juliana Ferreira Nunes (iD)

Universidade Federal Rural do Rio de Janeiro, Brasil http://lattes.cnpq.br/1970732921631427

http://orcid.org/0000-0001-8665-4192 jufnunes2@gmail.com
Isabel Arjonas Fernandes Avila (D)

Universidade Federal Rural do Rio de Janeiro, Brasil http://lattes.cnpq.br/4930300261090889 http://orcid.org/0000-0003-3713-1509 isabelarjonas@gmail.com

João Vitor da Silva Gonçalves (iD)

Universidade Federal Rural do Rio de Janeiro, Brasil http://lattes.cnpq.br/7118786392668574 http://orcid.org/0000-0002-1603-8252 joaovdsgoncalves@gmail.com

\section{Paula Fernanda Alves Ferreira (iD)}

Universidade Federal Rural do Rio de Janeiro, Brasil http://lattes.cnpq.br/4746910588907703 http://orcid.org/0000-0001-7533-1216 paula.faf@hotmail.com
Miliane Moreira Soares de Souza (iD)

Universidade Federal Rural do Rio de Janeiro, Brasil http://lattes.cnpq.br/0865211214618618 http://orcid.org/0000-0001-8325-9322 milianemss@gmail.com

\section{Shana de Mattos de Oliveira Coelho (D)}

Universidade Federal Rural do Rio de Janeiro, Brasil http://lattes.cnpq.br/3212438357088121 http://orcid.org/0000-0003-4165-5735 shana mattos@hotmail.com

\section{Irene da Silva Coelho (iD}

Universidade Federal Rural do Rio de Janeiro, Brasil http://lattes.cnpq.br/2191695584157582 http://orcid.org/0000-0003-1357-2529 irenecs@yahoo.com

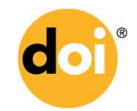

DOI: 10.6008/CBPC2179-6858.2021.004.0012

\section{Referencing this:}

SANT'ANNA, G. S. L.; CUNHA, J. M. F.; NUNES, J. F.; AVILA, I. A. F.; GONÇALVES, J. V. S.; FERREIRA, P. F. A.; SOUZA, M. M. S.; COELHO, S. M. O.; COELHO, I. S.. Antimicrobial resistance genes and bacterial diversity in sediments of Guandu River, Brazil. Revista Ibero Americana de Ciências Ambientais, v.12, n.4, p.116-123, 2021. DOI: http://doi.org/10.6008/CBPC2179-6858.2021.004.0012 


\section{INTRODUCTION}

The emergence of antimicrobial resistance genes represents a significant global health problem (TAYLOR et al., 2011). The magnitude of the problem worldwide affects environmental, animal and human health (WHO, 2014). Antimicrobial resistance has recently been widely examined from an environmental perspective, projecting new light on a problem that has traditionally been confined to a subset of clinically relevant resistant bacterial pathogens. Studies have revealed a crucial role of the environment in the spread and evolution of antimicrobial resistance in bacteria (BONDARCZUK et al., 2019).

Among the various environments, river systems have been received effluents from industrial and human activities and represent a unique scenario for the acquisition and dissemination of antimicrobial resistance genes (ARGs) and the proliferation of resistant bacteria (CHEN et al., 2019). Sediments are fundamental to understand the phenomenon of resistance in water systems. According to Chandran et al. (2011, cited by OHORE et al., 2019), "bacteria survive longer in sediments than in the water column, as they provide beneficial conditions for their nutrition and have a higher desorbing capacity of some antimicrobials". The presence of antimicrobials, heavy metals, and other residues might select different bacterial groups and subsequently change the microbial diversity and the antimicrobial resistance profile (OHORE et al., 2019). Rivers not only act as the pools of ARGs but also become the dispersal routes of resistant pathogens, increasing the risks for transmission back to humans (MARATHE et al., 2017; LARSSON et al., 2018).

The Guandu River and its hydrographic basin occupy 3,600 km, covering 15 municipalities in the Metropolitan and South-Central Regions of the State of Rio de Janeiro, Brazil. This basin is a peculiar characteristic, with no other example in the country, because much of the volume of water that composes it originates from the transposition of, on average, $120 \mathrm{~m}^{3} \mathrm{~s}^{-1}$ of the Paraíba do Sul River, in the municipality of Barra do Piraí (GUANDU COMMITTEE, 2012). The Guandu drinking water treatment plant supplies water to 10 million inhabitants of Rio de Janeiro's metropolitan region. However, the Paraíba do Sul System - Guandu is inserted in a region of high population and industrial occupation, also with significant agricultural production, with many environmental problems occurring: the natural release of domestic sewage in their water bodies, abrupt and irregular expansion of urban areas, pollution by industrial waste, mineral extraction (mainly sand), contamination by agricultural pesticides, deforestation of riparian forests (GUANDU COMMITTEE, 2012).

Independent cultivation techniques based on nucleic acids have been increasingly used in Environmental Microbiology studies. They allow reaching a larger portion of the bacterial community in their natural habitat since cultivable microorganisms represent less than $1 \%$ of the soil's microbial population (AMANN et al., 1995). We can extrapolate this advantage to studies of antimicrobial resistance where we can directly access antimicrobial resistance genes from the DNA of a broader range of soil bacteria and not only those grown in the culture medium. Therefore, this study aimed to evaluate antimicrobial resistance genes and microbial diversity in the Guandu River's sediments in Nova Iguaçu, Brazil, using the independent cultivation technique based on the nucleic acid. 


\section{MATERIALS AND METHODS}

\section{Sample collection}

Three sediment samples were collected upstream from the water catchment point of ETA Guandu (Water Treatment Plant), on the border between Nova Iguaçu and Seropédica, using a sterile collector. After the collection, the samples were stored in sterile plastic bags. The samples were transported in a refrigerated container and subsequently stored at $-20^{\circ} \mathrm{C}$.

\section{Total soil DNA extraction}

Total DNA extraction from soil samples was performed using the DNA PowerSoil kit (MO BIO, 2016), according to the protocol provided by the manufacturer. After extraction, the samples were stored at $-20^{\circ} \mathrm{C}$, and the quantity and quality of the DNA obtained were evaluated by spectrophotometer (THERMO SCIENTIFIC, 2010).

\section{Amplification of the 16S rRNA and antimicrobial resistance genes by PCR (Polymerase Chain Reaction)}

PCR reactions were optimized using initial parameters: Buffer $1 \mathrm{X}, 2.5 \mathrm{mM} \mathrm{MgCl}_{2}, 0.2 \mathrm{mM} \mathrm{dNTP}, 0.4$ $\mu \mathrm{M}$ of each primer, $1 \mathrm{U}$ Taq DNA Polymerase, about $20 \mathrm{ng}$ of total DNA, and ultra-pure water to complete the total volume of $25 \mu$ l. The primers selected and used are described in Table 1, as well as their sequences and fragment sizes.

Table 1: Sequence of primers and size of fragments generated in the amplification of the 165 rRNA gene and resistance

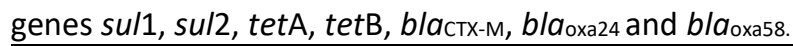

\begin{tabular}{|c|c|c|c|c|}
\hline Gene & Primer & Sequence & Fragment & Reference \\
\hline \multirow{2}{*}{$16 S$ rRNA } & $27 \mathrm{~F}$ & AGAGTTTGATCCTGGCTCAG & \multirow{2}{*}{1500 pb } & \multirow{2}{*}{ Lane (1991) } \\
\hline & $1512 R$ & ACGGCTACCTTGTTACGACT & & \\
\hline \multirow{2}{*}{ sul1 } & Sul $1 \mathrm{~F}$ & CGCACCGGAAACATCGCTGCA & \multirow{2}{*}{$162 \mathrm{pb}$} & \multirow{2}{*}{ Pei et al. (2006) } \\
\hline & Sul $1 \mathrm{R}$ & TGAAGTTCCGCCGCAAGGCTC & & \\
\hline \multirow{2}{*}{ sul2 } & Sul $2 \mathrm{~F}$ & TCCGGTGGAGGCCGGTATCTGG & \multirow{2}{*}{$190 \mathrm{pb}$} & \multirow{2}{*}{ Pei et al. (2006) } \\
\hline & Sul 2 R & CGGGAATGCCATCTGCCTTGAG & & \\
\hline \multirow{2}{*}{ tetA } & tetA F & GCGCGATCTGGTTCACTCG & \multirow{2}{*}{$164 \mathrm{pb}$} & \multirow{2}{*}{ Aminov et al. (2004) } \\
\hline & tetA R & AGTCGACAGYRGCGCCGGC & & \\
\hline \multirow{2}{*}{ tet $B$} & tetB $F$ & TACGTGAATTTATTGCTTCGG & \multirow{2}{*}{$206 \mathrm{pb}$} & \multirow{2}{*}{ Aminov et al. (2004) } \\
\hline & tetB R & ATACAGCATCCAAAGCGCAC & & \\
\hline \multirow{2}{*}{ bla $_{\mathrm{CTX}-\mathrm{M}}$} & $b / a_{\text {CTX-M }} F$ & AAAAATCACTGCGCCAGTTC & \multirow{2}{*}{$862 \mathrm{pb}$} & \multirow{2}{*}{ Geser et al. (2012) } \\
\hline & $b / a_{\mathrm{CTX}-\mathrm{M}} \mathrm{R}$ & CCGTCGGTGACGATTTTAAGCC & & \\
\hline \multirow{2}{*}{ oxa-24 } & \multirow{2}{*}{ oxa-24 F oxa-24 R } & CAGTGCATGTTCATCTATT & \multirow{2}{*}{$702 \mathrm{pb}$} & \multirow{2}{*}{ Chen et al. (2018) } \\
\hline & & TCTAAGTTGAGCGAAAAG & & \\
\hline \multirow{2}{*}{ oxa-51 } & \multirow{2}{*}{ oxa-51 F oxa-51 R } & TCCAAATCACAGCGCTTCAAAA & \multirow{2}{*}{$639 \mathrm{pb}$} & \multirow{2}{*}{ Chen et al. (2018) } \\
\hline & & TGAGGCTGAACAACCCATCCA & & \\
\hline \multirow[t]{2}{*}{ oxa-58 } & \multirow[t]{2}{*}{ oxa-58 F oxa-58 R } & AAGTATTGGGGCTTGTGCTG & \multirow[t]{2}{*}{$599 \mathrm{pb}$} & \multirow[t]{2}{*}{ Chen et al. (2018) } \\
\hline & & ССССTCTGCGCTCTACATAC & & \\
\hline
\end{tabular}

The protocol followed in the thermocycler for amplification of the 16S rRNA gene was: 5 minutes of

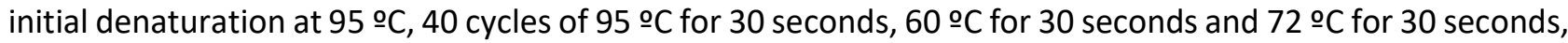
followed by a final elongation at 72 o $\mathrm{C}$ for 7 minutes. The following parameters were used to amplify the sulfonamide resistance genes: 5 minutes of initial denaturation at $95 \stackrel{\circ}{\circ}, 40$ cycles of $95 \stackrel{\circ}{\circ}$ for 30 seconds,

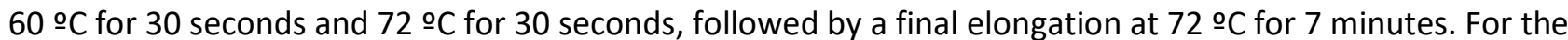


tet $\mathrm{A}$ and tet $\mathrm{B}$ genes, the amplification condition followed from 5 minutes of initial denaturation to $94^{\circ} \mathrm{C}, 40$ cycles of $94^{\circ} \mathrm{C}$ for 5 seconds and $61^{\circ} \mathrm{C}$ for 30 seconds, followed by a final elongation of $61^{\circ}$ for 7 minutes. The $b / a_{\mathrm{CTX}-\mathrm{M}}$ gene the amplification condition followed from 5 minutes of initial denaturation to 94 으, 40 cycles

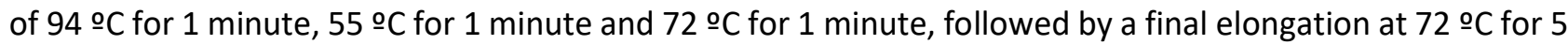
minutes. The $b / a_{\text {oxa24 }}$ and $b / a_{\text {oxass }}$ genes the amplification condition followed from 5 minutes of initial

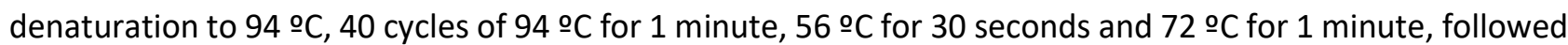
by a final elongation at 72 ㅇ $\mathrm{C}$ for 10 minutes. The positive control of PCR reactions was obtained by extracting DNA from antimicrobial-resistant strains of Escherichia coli isolated from chickens from poultry farms located in Rio de Janeiro.

PCR products were separated by electrophoresis in 1.5\% agarose gel containing SYBR Green dye (Life Technologies). The images were captured under UV light using the L-PIX EX (Loccus Biotecnologia) photo documentation system.

\section{Library preparation, sequencing of the 16s rRNA gene, and bioinformatics analysis}

The preparation of 16S rRNA library with amplicons of the variable region V3-V4 of the gene encodes 16S rRNA generated with amplification with primers Bakt_341F (CCTACGGGNGGCWGCA) and Bakt_805R (GACTACHVGGGTATCTAATCC) (PARADA et al., 2016) and sequencing in a $2 \times 250$ paired-end system on the MiSeq platform (Illumina, USA) were performed by Macrogen, Inc. (dna.macrogen.com).

The raw sequencing data were processed using the Mothur v.1.41.3 software (SCHLOSS et al., 2009). The forward and reverse sequences were paired in contigs. The sequences smaller than 245 base pairs (bp) or greater than 275 bp were removed, which contained ambiguity or more than eight homopolymers. Then, the sequences were aligned using a Silva database as a reference (QUAST et al., 2012). The resulting alignment was submitted to the screen.seqs and filter.seqs commands to remove misaligned sequences and non-informational columns in alignment. Then, the sequences were pre-grouped using the pre.cluster command using the parameter diffs $=2$. Chimeric sequences were detected and removed using the chimera.vsearch and remove.seqs commands, respectively. The resulting sequences were classified according to version 16 of the Ribosomal Database Project (COLE et al., 2009) using the classify.seqs command with a confidence threshold of 80 . Sequences identified as chloroplasts, mitochondria, eukaryotes or Archaea and those identified as unknown realms were also removed. After normalizing the samples for the same number of sequences, these were grouped into operational taxonomic units (OTUs) using the cluster.split command, with a dissimilarity threshold of $3 \%$. The rare OTUs were removed using the split.abund command and finally, the distribution of OTUs, the richness indexes of Chao (1984), of Shannon (2001) and Simpson (1949) and the rarefaction curves were calculated.

\section{RESULTS AND DISCUSSION}

The 16S rRNA gene was detected in all soil samples (Table 2), evidencing that there is DNA in quantity 
and quality for PCR amplification of genes encoding antimicrobial resistance.

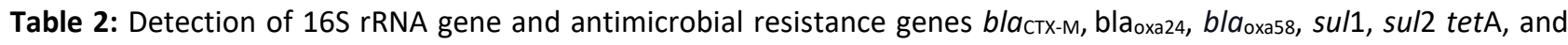
tetB in Guandu river sediments.

\begin{tabular}{lllllllll}
\hline \multicolumn{7}{l}{ Resistance genes } \\
\hline Samples & 16S rDNA & bla $a_{\mathrm{CTX}-\mathrm{M}}$ & bla $\mathrm{OXA24}$ & bla $\mathrm{OXA58}$ & sul1 & sul2 & tetA & tetB \\
\hline $\mathrm{A}$ & + & - & - & - & + & + & - & - \\
$\mathrm{B}$ & + & + & - & - & + & + & - & - \\
$\mathrm{C}$ & + & - & - & - & + & + & - & - \\
\hline
\end{tabular}

The genes encoding resistance to sulfonamides sul1 and sul2 were detected in all three samples. The genes encoding resistance to tetracyclines tet $\mathrm{A}$ and $t e t \mathrm{~B}$ and the $\mathrm{bla}_{\text {oxa24 }}$ and $b / a_{\text {oxa5s }}$ genes were not detected in any samples. The bla $a_{\mathrm{CTX}-\mathrm{M}}$ gene (responsible for CTX-M beta-lactamase production) was detected only in one sample (sample B).

Studies indicate that the most abundant and diverse antimicrobial resistance genes in the river system are associated with drugs widely used in this area, suggesting dissemination due to selective pressure resulting from antimicrobials (CHEN et al., 2019). Furthermore, various contaminants such as metals, biocides, and other pollutants may accumulate in the sediments that act as a reservoir of pollutants and inadvertently promote resistant bacteria's persistence (CHENG et al., 2014). It indicates that river sediments may be one of the crucial reservoirs of antimicrobial resistance due to the selective pressure resulting from discarding the waste from industries, from the urban and agricultural in the river.

OTU rarefaction curves tended to reach the plateau with the total number of sequences analyzed (Figure 1), which indicates that the sampling effort was sufficient to cover the existing diversity. That is, the increase in value would have a minimal impact on the number of OTUs (HUGHES et al., 2005).
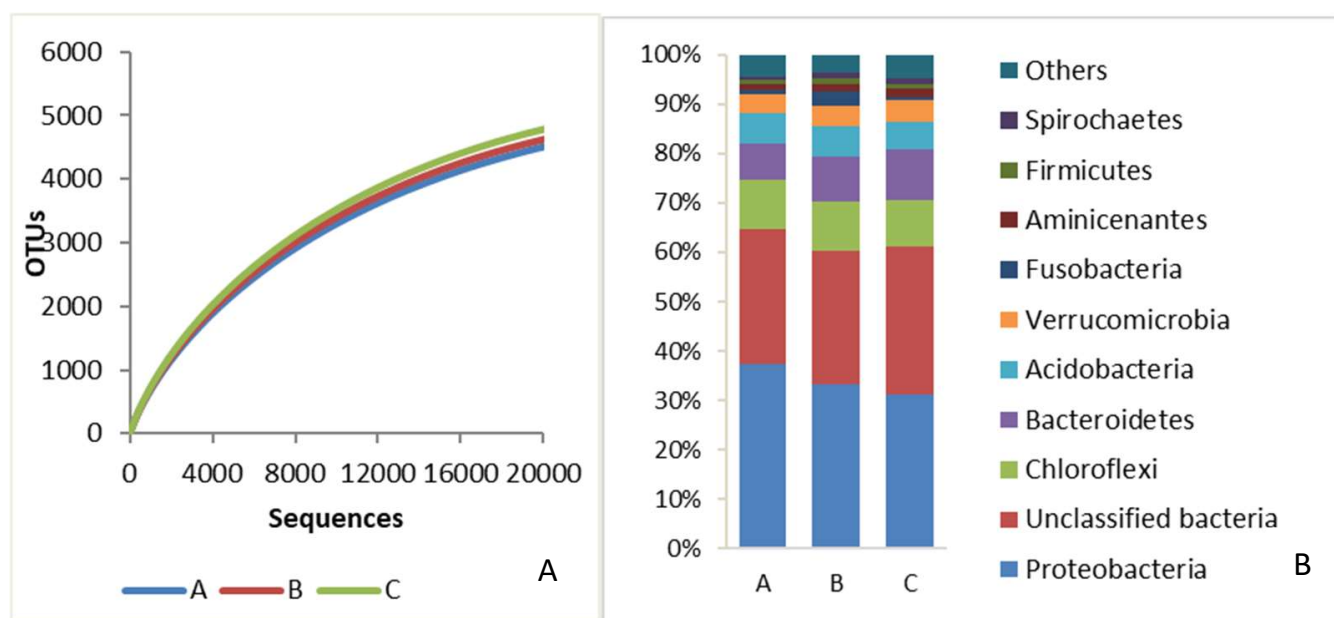

Figure 1: (A) OTU rarefaction curves with $97 \%$ similarity per sample of Guandu River sediments. (B) Bacterial phyla with an average relative abundance higher than $1 \%$ found in Guandu river sediments.

The dominant bacterial phylum in sediments was Proteobacteria, followed by Chloroflexi, Bacteroidetes, and Acidobacteria. The results of diversity in temperate and tropical climate rivers present a pattern already reported in the literature, and the phylogenetic groups are the most abundant (KÖCHLING et al., 2017). 
Proteobacteria are the most common, being the dominant phylum in the riverine system. According to Köchling et al. (2017) Chloroflexi and Acidobacteria phyla can be almost exclusively found in sediments. Bacteria of the class Gammaproteobacteria have colonized several different environments because they present wide metabolic diversity (WANG et al., 2012). They can be found on the surface of sediments and are associated with environments rich in organic matter and being involved with sulphur reduction (HALLER et al., 2011; WANG et al., 2012). It is common in more polluted environments to find bacteria of the Beta and Deltaproteobacteria classes, where the latter class is typical to find sulphate and iron reducers (FellI); betaprotobacteria are degrading and recalcitrant, but both are found in contaminated sediments (HALLER et al., 2011).

Chloroflexi phylum's presence abundantly in three sediment samples is suggested for its essential role in the degradation of organic material in the environment (KÖCHLING et al., 2017). Acidobacteria has its abundance related to specific pollutants, and in other reports, it was a predominant phylum in the analysis of microbial diversity of sediments with the Chloroflexi (KÖCHLING et al., 2017).

Regarding the phylum Bacteriodetes, they are saprophyte organisms, specialized in the mineralization of organic material, directly involved in its degradation contributing to the flow of carbon within the ecosystem (THOMAS et al., 2011). They are found as the river's depth increases, concluding that they are efficient in degrading macromolecules (LAPÉBIE et al., 2019). The presence of this phylum, Bacterioidales and Bacteroides are associated with high contamination with organic matter, especially fecal contamination (KÖCHLING et al., 2017).

Fusobacteria is more found in the oral cavity and present in intestinal tracts (OLSEN, 2014). The discharge of raw sewage at the sampling point suggests that the family's presence is mainly associated with domestic effluent. In the section of The Fusobacterias Family, Olsen (2014) shows that some fusobacterias "as F. nucleatum exhibited a significant portion of beta-lactamase producers, which may deteriorate treatment with beta-lactam antimicrobials". A gene that confers resistance to beta-lactams was found in one of our samples.

Studies indicate that beta-lactamase production increases in some Bacteroides and Fusobacteria, showing a great one health concern about which antimicrobial would still be suitable for future infections caused by these bacteria (OLSEN, 2014). These results express a significant concern that riverine systems could act as a reservoir of antimicrobial resistance.

\section{CONCLUSIONS}

Proteobacteria was the most abundant phylum, presenting a pattern reported in the literature for diversity in tropical and temperate climate river sediments. The presence of antimicrobial resistance genes

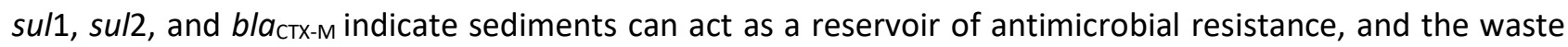
from industries, from the urban and agricultural environment, can increase the persistence of resistance in bacterial communities through the selection pressure of antimicrobials, biocides and heavy metals. These 
findings provide new data about the bacterial community and antimicrobial resistance genes in Brazilians river sediments.

ACKNOWLEDGMENTS: We thank the following research funding agencies for financial support: CNPq (Conselho Nacional de Desenvolvimento Científico e Tecnológico), CAPES (Coordenação de Aperfeiçoamento de Pessoal de Nível Superior) and FAPERJ (Fundação Carlos Chagas Filho de Amparo à Pesquisa do Estado do Rio de Janeiro). No conflicts of interests.

\section{REFERENCES}

AMANN, R. I.; LUDWIG, W.; SCHLEIFER, K. H.. Phylogenetic identification and in situ detection of individual microbial cells without cultivation. Microbiology and Molecular Biology Reviews, v.59, n.1, p.143-169, 1995.

AMINOV, R. I.; CHEE-SANFORD, J. C.; GARRIGUES, N.; MEHBOOB, A.; MACKIE, R. I.. Detection of tetracycline resistance genes by PCR methods. Public Health Microbiology, p.3-13, 2004. DOI: http://doi.org/10.1385/159259-766-1:003

BONDARCZUK, K.; PIOTROWSKA-SEGET, Z.. Microbial diversity and antibiotic resistance in a final effluent-receiving lake. Science of the Total Environment, v.650, p.2951-2961, 2019. DOI: https://doi.org/10.1016/j.scitotenv.2018.10.050

CHANDRAN, A.; VARGHESE, S.; KANDELER, E.; THOMAS, A.; HATHA, M.; MAZUMDER, A.. An assessment of potential public health risk associated with the extended survival of indicator and pathogenic bacteria in freshwater lake sediments. International journal of hygiene and environmental health, v.214, n.3, p.258-264, 2011. DOI: https://doi.org/10.1016/i.ijheh.2011.01.002

CHAO, A.. Nonparametric estimation of the number of classes in a population. Scandinavian Journal of statistics, p.265-270, 1984. DOI:

https://doi.org/10.1016/i.scitotenv.2018.10.050

CHEN, H.; BAI, X.; JING, L.; CHEN, R.; TENG, Y..

Characterization of antibiotic resistance genes in the sediments of an urban river revealed by comparative metagenomics analysis. Science of the Total Environment, v.653, p.1513-1521, 2019. DOI:

https://doi.org/10.1016/j.scitotenv.2018.11.052

CHENG, D.; LIU, X.; WANG, L.; GONG, W.; LIU, G.; FU, W.; CHENG, M.. Seasonal variation and sediment-water exchange of antibiotics in a shallower large lake in North China. Science of the Total Environment, v.476, p.266-275, 2014. DOI: http://doi.org/10.1016/j.scitotenv.2014.01.010

COLE, J. R.; WANG, Q.; CARDENAS, E.; FISH, J.; CHAI, B.; FARRIS, R. J.; KULAM-SYED-MOHIDEEN, A. S.; MCGARRELI, D. M.; MARSH, T.; GARRITY, G. M.; TIEDJE, J. M.. The Ribosomal Database Project: improved alignments and new tools for rRNA analysis. Nucleic acids research, v.37, p.D141-D145, 2009. DOI: https://doi.org/10.1093/nar/gkn879

GESER, N.; STEPHAN, R.; HÄCHLER, H.. Occurrence and characteristics of extended-spectrum $\beta$-lactamase (ESBL) producing Enterobacteriaceae in food producing animals, minced meat and raw milk. BMC veterinary research, v.8, n.1, p.21, 2012. DOI: http://doi.org/10.1186/1746-6148-8$\underline{21}$

GUANDU COMMITTEE. Comitê da Bacia Hidrográfica Guandu (RJ). Bacia Hidrográfica dos Rios Guandu, da Guarda e Guandu-Mirim: experiências para a gestão dos recursos hídricos. Rio de Janeiro: INEA, 2012.

HALLER, L.; TONOLLA, M.; ZOPFI, J.; PEDUZZI, R.; WILDI, W.; POTE, J.. Composition of bacterial and archaeal communities in freshwater sediments with different contamination levels (Lake Geneva, Switzerland). Water research, v.45, n.3, p.1213-1228, 2011. DOI: https://doi.org/10.1016/j.watres.2010.11.018

HUGHES, J. B.; HELLMANN, J. J.. The Application of Rarefaction Techniques to Molecular Inventories of Microbial Diversity. Environmental Microbiology, v.397, p.292-308, 2005. DOI: https://doi.org/10.1016/S00766879(05)97017-1

KÖCHLING, T.; SANZ, J. L.; GALDINO, L.; FLORENCIO, L.; KATO, M. T.. Impact of pollution on the microbial diversity of a tropical river in an urbanized region of northeastern Brazil. Int Microbiol, v.20, n.1, p.11-24, 2017. DOI: http://doi.org/10.2436/20.1501.01.281

LANE, D. J.. 16S/23S rRNA Sequencing. In: STACKEBRANDT, E.; GOODFELLOW, M.. Nucleic Acid Techniques in Bacterial Systematic. New York: John Wiley and Sons, 1991. p.115175.

LAPÉBIE, P.; LOMBARD, V.; DRULA, E.; TERRAPON, N.; HENRISSAT, B.. Bacteroidetes use thousands of enzyme combinations to break down glycans. Nature communications, v.10, n.1, p.1-7, 2019. DOI: http://doi.org/10.1038/s41467-019-10068-5

LARSSON, D. G. J.; ANDREMONT, A.; BENGTSSIN-PALME, J.; BRANDT, K. K.; HUSMAN, A. M. R.; FAGERSTEDT, P.; FICK, J.; FLACH, C. F.; GAZE, W. H.; KURODA, M.; KVINT, K.; LAXMINARAYAN, R.; MANAIA. C. M.; NIELSEN, K. M.; PLANT, L.; PLOY, M. C.; SEGOVIA, C.; SIMONET, P.; SMALLA, K.; SNAPE, J.; TOPP, E.; VAN HENGEL, A. J.; VERNER-JEFFREYS, D. W. VIRTA, M. P. J.; WELLINGTON, E. M.; WERNERSSON, A. S.. Critical knowledge gaps and research needs related to the environmental dimensions of antibiotic resistance. 
Environment International., v.117, p.132-138, 2018. DOI: https://doi.org/10.1016/i.envint.2018.04.041

MARATHE, N. P.; PAL, C.; GAIKWAD, S. S.; JONSSON, V.; KRISTIANSSON, E.; LARSSON, D. J.. Untreated urban waste contaminates Indian river sediments with resistance genes to last resort antibiotics. Water Research. 124, p.388-397, 2017. DOI: https://doi.org/10.1016/j.watres.2017.07.060

MO BIO. PowerSoil ${ }^{\circledR}$ DNA Isolation Kit Instruction Manual. California: Mo Bio Laboratories Inc., 2016.

OHORE, O. E.; ADDO, F. G.; ZHANG, S.; HAN, N.; ANIM-LARBI, K.. Distribution and relationship between antimicrobial resistance genes and heavy metals in surface sediments of Taihu Lake, China. Journal of Environmental Sciences, v.77, p.323-335, 2019. DOI: http://doi.org/10.1016/j.jes.2018.09.004

OLSEN, I.. The Family Fusobacteriaceae. In ROSENBERG, E.; DELONG. E. F.; LORY, S.; STACKEBRANDT, E.; THOMPSON, F.. The prokaryotes: Firmicutes and tenericutes. Berlin Heidelberg: Springer, 2014. p.109-132.

PARADA, A. E.; NEEDHAM, D. M.; FUHRMAN, J. A.. Every base matters: assessing small subunit rRNA primers for marine microbiomes with mock communities, time series and global field samples. Environmental microbiology, v.18, n.5, p.1403-1414, 2016. DOI: https://doi.org/10.1111/1462$\underline{2920.13023}$

PEI, R.; KIM, S. C.; CARLSON, K. H.; PRUDEN, A.. Effect of river landscape on the sediment concentrations of antibiotics and corresponding antibiotic resistance genes (ARG). Water research, v.40, n.12, p.2427-2435, 2006. DOI: https://doi.org/10.1016/i.watres.2006.04.017

QUAST, C.; PRUESSE, E.; YILMAZ, P.; GERKEN, J.; SCHWEER, T.; YARZA, P.; PEPLIES, J.; GLÖCKNER, F. O.. The SILVA ribosomal RNA gene database project: improved data processing and web-based tools. Nucleic acids research, v.41, n.D1, p.D590-D596, 2012. DOI:

https://doi.org/10.1093/nar/gks1219
SCHLOSS, P. D.; WESTCOTT, S. L.; RYABIN, T.; HALL, J. R.; HARTMANN, M.; HOLLISTER, E. B.; LESNIEWSKI, R. A.; OAKLEY, B. B.; PARKS, D. H.; ROBINSON, C. J.; SAHL, J. W.; STRES, B.; THALLINGER, G. G.; VAN HORN, D. J.; WEBER, C. F.. Introducing mothur: open-source, platform-independent, community-supported software for describing and comparing microbial communities. Applied and environmental microbiology, v.75, n.23, p.7537-7541, 2009. DOI: http://doi.org/10.1128/AEM.01541-09

THERMO SCIENTIFIC. NanoDrop ${ }^{\circledR} 1000$ Spectrophotometer V3. 8 User's Manual. Delaware: Thermo Fisher Scientific Inc., 2010.

SHANNON, C. E.. A mathematical theory of communication. ACM SIGMOBILE mobile computing and communications review, v.5, n.1, p.3-55, 2001. DOI: https://doi.org/10.1145/584091.584093

SIMPSON, E. H.. Measurement of diversity. Nature, v.163, n.4148, p.688-688, 1949. DOI:

https://doi.org/10.1038/163688a0

TAYLOR, N. G. H.; VERNER-JEFFREYS, D. W.; BAKER-AUSTIN, C.. Aquatic systems: maintaining, mixing and mobilising antimicrobial resistance?. Trends in ecology \& evolution, v.26, n.6, p.278-284, 2011. DOI:

https://doi.org/10.1016/j.tree.2011.03.004

THOMAS, F.; HEHEMANN, J. H.; REBUFFET, E.; CZJZEK, M.; MICHEL, G.. Environmental and gut bacteroidetes: the food connection. Frontiers in microbiology, v.2, p.93, 2011. DOI: https://doi.org/10.3389/fmicb.2011.00093

WANG, Y.; SHENG, H. F.; HE, Y.; WU, J. Y.; JIANG, Y. X.; TAM, N. F. Y.; ZHOU, H. W.. Comparison of the levels of bacterial diversity in freshwater, intertidal wetland, and marine sediments by using millions of illumina tags. Applied and environmental microbiology, v.78, n.23, p.8264-8271, 2012. DOI: http://doi.org/10.1128/AEM.01821-12

WHO. World Health Organization. Antimicrobial resistance: global report on surveillance. Switzerland: World Health Organization, 2014.

A CBPC - Companhia Brasileira de Produção Científica (CNPJ: 11.221.422/0001-03) detém os direitos materiais desta publicação. Os direitos referem-se à publicação do trabalho em qualquer parte do mundo, incluindo os direitos às renovações, expansões e disseminações da contribuição, bem como outros direitos subsidiários. Todos os trabalhos publicados eletronicamente poderão posteriormente ser publicados em coletâneas impressas sob coordenação da Sustenere Publishing, da Companhia Brasileira de Produção Científica e seus parceiros autorizados. Os (as) autores (as) posteriormente ser publicados em coletâneas impressas sob coordenação da Sustenere Publishing, da Companhia Brasileira de Produção Cientifica e seus parce
preservam os direitos autorais, mas não têm permissão para a publicação da contribuição em outro meio, impresso ou digital, em português ou em tradução. 